\title{
Heavy Metal Concentrations in Selected Fishes, and Water from Orogodo River, Agbor, Delta State in Nigeria
}

\author{
O. M. Wangboje ${ }^{1^{*}}$, P. C. Ekome ${ }^{1}$ and U. I. Efendu ${ }^{2}$ \\ ${ }^{1}$ Department of Fisheries, Faculty of Agriculture, University of Benin, P.M.B. 1154, Benin City, Nigeria. \\ ${ }^{2}$ Agriculture Central Laboratory, Faculty of Agriculture, University of Benin, P.M.B. 1154, Benin City,
}

Nigeria.

\section{Authors' contributions}

This work was carried out in collaboration between all authors. Authors OMW and PCE designed the study. Author PCE performed the statistical analysis, wrote the protocol and wrote the first draft of the

manuscript. Author UIE managed the analyses of the study. Authors OMW and PCE managed the literature searches. All authors read and approved the final manuscript.

Article Information

DOI: $10.9734 / \mathrm{AJEE} / 2017 / 33608$

Editor(s):

(1) Wen-Cheng Liu, Department of Civil and Disaster Prevention Engineering, National United University, Taiwan and Deputy Director General, Taiwan Typhoon and Flood Research Institute, National United University, Taipei, Taiwan.

Reviewers.

(1) Arnaldo Sarti, Universidade Estadual Paulista, Brazil. (2) H.O. Nwankwoala, University of Port Harcourt, Nigeria. (3) Beaven Utete, Chinhoyi University of Technology, Zimbabwe. Complete Peer review History: http://www.sciencedomain.org/review-history/19620

Original Research Article

Received 22 $2^{\text {nd }}$ April 2017

Accepted $29^{\text {th }}$ May 2017

Published $20^{\text {th }}$ June 2017

\begin{abstract}
This study determined heavy metal:- (lead (Pb), cadmium (Cd), copper (Cu), zinc (Zn) and iron (Fe) concentrations in selected fish species including: (Brycinus intermidus, Clarias gariepinus, Parachanna obscura, Ctenopoma kingsleyae, Hemichromis bimaculatus and Phractolaemus ansorgeii) and water from Orogodo River situated in Agbor, Delta State, Nigeria. Furthermore, the health risk exposure to humans who consume the fish and utilized the water in Orogodo River was assessed. The mean $( \pm S D)$ concentration of the heavy metal in water ranged from $0 \pm 0 \mathrm{mg} / \mathrm{l}$ for $\mathrm{Cd}$ to $0.35 \pm 0.29 \mathrm{mg} / \mathrm{l}$ for Fe. The mean ( $\pm S D$ ) concentration of metals in fish species ranged from $0.06 \pm 0.02 \mathrm{mg} / \mathrm{kg}$ for $\mathrm{Cd}$ in Brycinus intermidus to $187.90 \pm 89.59 \mathrm{mg} / \mathrm{kg}$ for $\mathrm{Fe}$ in Parachanna obscura. The Bioaccumulation Quotient (BQ) values ranged from $4.51 \mathrm{mg} / \mathrm{kg}$ for $\mathrm{Pb}$ in Hemichromis bimaculatus to $1297.13 \mathrm{mg} / \mathrm{kg}$ for Fe in Phractolemus ansorgei. These results imply that continuous intake of fish and water obtained from this river would have cumulative deleterious effect on aquatic organisms and man.
\end{abstract}


Keywords: Heavy metals; fish; water; bioaccumulation quotient; health risks; Orogodo River; Nigeria.

\section{INTRODUCTION}

Threats from pollutants in water supplies are under the spotlight owing to the associated adverse effects of the pollutants on hydrobionts and aquatic habitat integrity [1]. Heavy metals are toxic as they are persistent, nonbiodegradable and readily accumulate in water, soil, bottom sediments and living organisms. Currently, there is an increasing ecological and global public health concern associated with environmental contamination by heavy metals. Heavy metals are ubiquitous and chemically stable, so they can be expected to be present in all parts of the biotic and abiotic matter. Heavy metals may be directly absorbed by organisms but are also transferred from lower to higher trophic levels of the food chain. The high accumulation of heavy metals in these components can result in serious ecological changes.

Also, human exposure to heavy metals has risen dramatically as a result of an exponential increase of their use in several industrial, agricultural, domestic and technological applications [2].

Heavy metal pollution affects aquatic ecosystem integrity as metals tend to be accumulative in the trophic food webs with apex predators like crocodiles [3] and human beings at health risk [4] Severity of the exposure risks derives from the persistent and accumulative nature of the metal species in the water phase $[5,6]$. As well, the contributions of the point and non-point sources of metal pollution determines their concentrations in a water body [7]. For the Agbor State in Nigeria, major anthropogenic sources of heavy metal pollution are mining and smelting activities, atmospheric deposition, disposal of untreated/ partially treated urban and industrial effluents, metal chelates from different industries, and haphazard use of heavy metal-containing fertilizers and pesticides during agricultural activities [8,9].

Regardless, heavy metals are some of the major contaminating agents in our food supply $[8,10,4]$. Fish absorb heavy metals from the surrounding water through a number of pathways though (not exclusive) for most species the gills are the primary route for the uptake of water borne pollutants $[11,12,13,14]$. The communities through which the Orogodo River transverses are predominantly engaged in agricultural activities which are heavily reliant on inorganic fertilisers, thus the river is subject to dumping of deleterious agricultural wastes. The Orogodo River also serves as the drainage point for all run off wastewater produced industrially or domestically within the Agbor metropolis and beyond. Because a majority of the drainage channels constructed by the State and Local Government within the Agbor metropolis and surrounding villages, aimed at controlling flooding and checking erosion are channelled directly into the river at various points along the river length.

Despite that most Agbor State community members diversify into fishing in the Orogodo River as an alternative livelihood, and to sustain and supplement their nutritional requirements especially in the off agricultural season. Fish forms part of their meal intake, however, humans may be at risk due to metal contamination in fish tissues and water derived from catchment pollution. Thus, it is imperative to assess metal pollution in the water phase and the different fish species utilised by the communities along the Orogodo River. It is prudent as well to estimate the health risks posed by exposure to river water and consumption of fish therein. This study aimed to determine the concentrations of heavy metal $(\mathrm{Pb}, \mathrm{Cd}, \mathrm{Cu}, \mathrm{Fe}$ and $\mathrm{Zn})$ in water and selected fish species in the Orogodo River in Agbor located in the Delta state in Nigeria. The underlying objective was to estimate the health risks posed by exposure water and consumption of fish from the river.

\section{MATERIALS AND METHODS}

\subsection{Study Area}

The study was conducted along Orogodo River which is located within Latitude $5^{\circ} 43^{\prime} \mathrm{N}$ and 5930' $\mathrm{N}$ and Longitude 620'E and 6912'E (Fig. 1).

The geology of the area is mainly of the recent tertiary sedimentary sand stone. The climate of the study area exhibits the characteristics of a sub equatorial climate with an annual mean air temperature of $27^{\circ} \mathrm{C}$ [9]. The rainfall pattern is that of double peaks or maximal with mean annual rainfall of $2,225 \mathrm{~mm}$; while the mean relative humidity is $81 \%$, and the soil type is redyellow ferrasols [15]. The rainy season is brought about by the South-West Trade Wind blowing across the Atlantic Ocean, while the dry, dusty, and often cold North-East Trade Wind blowing 
across the Sahara desert dominates the dry season with a short spell of Harmattan [16]. The River has its source at Mbiri village at an elevation of $150 \mathrm{~m}$ above sea level. It meanders and flows through Agbor and Abavo communities, both in Ika South Local Government Area to Obazagbon-Nugu and Evboesi both in Orhionmwon Local Government Area, Edo State and finally empties into a swamp near Abraka in Delta state [17]. Three sampling stations were established along the stretch of the river at Mbiri $\left(6.30^{\circ} \mathrm{N}, 6.27^{\circ} \mathrm{E}\right)$, Agbor $\left(6.25^{\circ} \mathrm{N}\right.$, $6.20^{\circ} \mathrm{E}$ ) and Obazagbon (6.20N, 6.40 E) with the most upstream study site at station one (Mbiri) and the most downstream at station three (Obazagbon). The three sites were chosen so as to adequately reflect and capture the pollution across the different land use patterns available in the study area.

\subsection{Sample Collection}

Fish species were caught by the local fishermen using gill nets. The fish samples were then icepacked and transported to the laboratory where they were identified using literature (key) as provided by Idodo Umeh (2003) and photographed using a digital camera (8.0 Megapixels). Water samples were collected once monthly using $1 \mathrm{~L}$ capacity plastic bottle with screw cap at a depth of 0-0.5 m at each sampling station. The study was carried out from November 2015 - April 2016.

\subsection{Digestion and Analysis}

The acid digestion process used for both the water and fish is a strong digestion method and was chosen so that the total metal content could be estimated. The water sample was aspirated into a flame and atomised. Metals in the sediments were also analysed using FAAS, after acid digestion to extract the metals from the sediments. This procedure consisted of two parts. (1) Digestion: the sediments were ovendried at $75^{\circ} \mathrm{C}$ in an analytical oven (DHG-9023A) until constant weight was attained. Then $5 \mathrm{ml}$ nitric acid and $2 \mathrm{ml}$ perchloric acid were added to $1 \mathrm{~g}$ of the oven-dried sample. The mixture was heated on a hot plate until fumes were produced and allowed to cool to room temperature. (2) Acidification: $5 \mathrm{ml}$ of $50 \%$ hydrochloric acid was added to the mixture from the first digestion. The acidified mixture was heated until boiling and then was cooled to room temperature. The acidified mixture was filtered and distilled water was added to the filtrate in a volumetric flask up to the $100 \mathrm{ml}$ mark. Fish digest and water samples were analyzed for $\mathrm{Cu}, \mathrm{Zn}, \mathrm{Fe}, \mathrm{Cd}$ and $\mathrm{Pb}$ by means of an Atomic Absorption Spectrophotometer AAS (PG Instruments AA500F series, Leicestershire,United Kingdom) equipped with solar software using air acetylene flame and also with lamp with Ultraviolet wavelength changed at intervals for the analysis of each metal [18].

\subsection{Quality Control}

Quality control was assured by the use of procedural blanks and standards. In each case a known concentration of the standard solution was assayed after every 10 samples to verify the analytical quality of the result because there was no standard reference material available. In all the cases for water and fish, a preparation/reagent blank was prepared for every 20 samples and all the concentrations were below the detection limits. Each sample was analysed in triplicate for repeatability with a relative SD $<5 \%$ for all metals analysed. Concentrations of $\mathrm{Cu}, \mathrm{Zn}, \mathrm{Fe}, \mathrm{Cd}$ and $\mathrm{Pb}$ were then determined using AAS ( $\mathrm{Cu}, \mathrm{Pb}, \mathrm{Zn}, \mathrm{Cd}, \mathrm{Fe}$, $\mathrm{Ni}$ and $\mathrm{Cr}$ in liver, gills, kidney and muscle were then determined using FAAS [18]. The concentration of heavy metals in water was expressed in $\mathrm{mg} / \mathrm{l}$, while concentration values in digested fish samples were expressed in $\mathrm{mg} / \mathrm{kg}$.

\subsection{Calculation of Bioaccumulation Quotient (BQ) for Heavy Metals}

This expresses the ability of fish to accumulate heavy metals above environmental concentrations [19].

$$
\mathrm{BQ}=\frac{\text { Heavy metal concentration in fish }(\mathrm{mg} / \mathrm{kg})}{\text { Heavy metal concentration in water }(\mathrm{mg} / \mathrm{l})}
$$

A $B Q$ value $>1$ indicates bioaccumulation of a heavy metal by fish.

\subsection{Statistical Analysis}

Data generated from the study were analyzed using GENSTAT computer software (Version 12.1 for Windows). One-way analysis of variance (ANOVA) was used to test for significant differences between mean values of metals at $5 \%$ level of probability. New Duncan multiple range test was used to separate significant means. 


\section{RESULTS}

\subsection{Heavy Metals in Water}

Mean concentration of $\mathrm{Pb}$ in water ranged from Non-Detectable, $0 \mathrm{mg} / \mathrm{l}$ in November to $0.03 \mathrm{mg} / \mathrm{l}$ in January while a mean $\mathrm{Pb}$ concentration of $0.013 \mathrm{mg} / \mathrm{l}$ was recorded for the study period. Station one recorded the highest concentration of $\mathrm{Pb}$ in water $(0.20 \mathrm{mg} / \mathrm{l})$ while the least $\mathrm{Pb}$ concentration was observed in station three $(0.008 \mathrm{mg} / \mathrm{l})$. Cadmium concentration in water during the study ranged from ND, $0 \mathrm{mg} / \mathrm{l}$ in November, December, and February to $0.07 \mathrm{mg} / \mathrm{l}$ in January while station three recorded the highest $\mathrm{Pb}$ concentration in water $(0.008 \mathrm{mg} / \mathrm{l})$. Mean concentration of $\mathrm{Cu}$ recorded during the study ranked highest in November, March and April $(0.04 \mathrm{mg} / \mathrm{l})$ while the least concentration was recorded in January $(0.01 \mathrm{mg} / \mathrm{l})$. The mean concentration of $\mathrm{Zn}$ in water ranged from 0.04 $\mathrm{mg} / \mathrm{l}$ in January to $0.17 \mathrm{mg} / \mathrm{l}$ in December while a mean concentration of $0.08 \mathrm{mg} / \mathrm{l}$ was recorded during the study. Station three recorded the highest mean concentration of $\mathrm{Zn}(0.095 \mathrm{mg} / \mathrm{l})$ while the least concentration was observed in station two $(0.077 \mathrm{mg} / \mathrm{l})$. The mean concentration of $\mathrm{Fe}$ in the sampled stations varied between $0.122 \mathrm{mg} / \mathrm{l}$ for station two to $0.195 \mathrm{mg} / \mathrm{l}$ in station three while the mean concentration of $0.15 \mathrm{mg} / \mathrm{l}$ was observed during the study. There were no significant differences $(p>0.05)$ in the mean concentration of $\mathrm{Pb}, \mathrm{Cd}, \mathrm{Cu}, \mathrm{Zn}$ and $\mathrm{Fe}$ in water between the sampled stations. Significant differences $(p<0.05)$ were observed in the mean concentration of $\mathrm{Cd}$, $\mathrm{Cu}$ and $\mathrm{Fe}$ in water between the sampled months while no significant differences were observed in the mean concentration of $\mathrm{Pb}$ and $\mathrm{Zn}$ between sampled months. Overall, the concentrations of $\mathrm{Pb}$ and $\mathrm{Cd}$ surpassed the WHO and most probably the local effluent standards (Table 2 ).

\subsection{Heavy Metals in Fish}

The mean concentration of $\mathrm{Pb}$ in fish during the study ranged from $0.60 \mathrm{mg} / \mathrm{kg}$ in November to $2.68 \mathrm{mg} / \mathrm{kg}$ in March (Table 3), while a mean concentration of $1.82 \mathrm{mg} / \mathrm{kg}$ was observed during the study. Mean concentration of $\mathrm{Pb}$ in fish species ranged from $0.06 \mathrm{mg} / \mathrm{kg}$ in $H$. fasciatus to $2.76 \mathrm{mg} / \mathrm{kg}$ in $P$. ansorgei. The mean concentration of $\mathrm{Cd}$ in fish during the study ranged from $0.03 \mathrm{mg} / \mathrm{kg}$ in December to 0.47 $\mathrm{mg} / \mathrm{kg}$ in January while mean concentration of $\mathrm{Cd}$ in fish species ranged from $0.06 \mathrm{mg} / \mathrm{kg}$ in $B$. intermidus to $0.615 \mathrm{mg} / \mathrm{kg}$ in $P$. obscura. The mean concentration of $\mathrm{Cu}$ in fish during the study ranged from $1.97 \mathrm{mg} / \mathrm{kg}$ in November to 10.57 $\mathrm{mg} / \mathrm{kg}$ in April while mean concentration of 6.71 $\mathrm{mg} / \mathrm{kg}$ was recorded during the study. Mean concentration of $\mathrm{Cu}$ in fish species ranged from $1.34 \mathrm{mg} / \mathrm{kg}$ in $C$. kingsleyea to $10.07 \mathrm{mg} / \mathrm{kg}$ in $P$. ansorgei. The mean concentration of $\mathrm{Fe}$ in fish during the study ranged from $3.5 \mathrm{mg} / \mathrm{kg}$ in November to $286.1 \mathrm{mg} / \mathrm{kg}$ in December while a mean concentration of $129.72 \mathrm{mg} / \mathrm{kg}$ was observed during the study (Table 3). Mean concentration of $\mathrm{Fe}$ in fish species ranged from $5.70 \mathrm{mg} / \mathrm{kg}$ in $C$. kingsleyea to $274.15 \mathrm{mg} / \mathrm{kg}$ in $P$. ansorgei. The mean concentration of $\mathrm{Zn}$ in fish during the study ranged from $22.96 \mathrm{mg} / \mathrm{kg}$ in February to $82.30 \mathrm{mg} / \mathrm{kg}$ in January while mean concentration of $61.62 \mathrm{mg} / \mathrm{kg}$ was recorded for the study. Mean concentration of $\mathrm{Zn}$ in fish species ranged from $14.08 \mathrm{mg} / \mathrm{kg}$ in $H$. bimaculatus to $91.62 \mathrm{mg} / \mathrm{kg}$ in $P$. obscura. No significant difference was observed in the mean concentration of $\mathrm{Cd}$ in all fish species sampled between months. Significant differences were observed in the mean concentration of $\mathrm{Pb}, \mathrm{Cu}$, $\mathrm{Zn}$ and $\mathrm{Fe}$ in all fish species caught during the study except Ctenopoma kingsleyea between months. Significant differences were observed in mean concentration of $\mathrm{Cd}, \mathrm{Cu}, \mathrm{Zn}$ and $\mathrm{Fe}$ between months while no significant difference was recorded in the mean concentration of $\mathrm{Pb}$ between months.

$\mathrm{Pb}, \mathrm{Zn}$ and Fe surpassed the FAO tissue level thresholds and most probably the local thresholds, and this is more significant for human health.

\subsection{Bioaccumulation Quotient Values for Chemical Elements}

(BQ)

The $\mathrm{BQ}$ values ranged from 4.51 for $\mathrm{Pb}$ in $H$. bimaculatus to 1297.13 for $\mathrm{Fe}$ in $P$. ansorgei.

\section{DISCUSSION}

\subsection{Heavy Metals in Water}

Mean concentration of $\mathrm{Pb}$ ranked highest in Mbiri as compared to other stations; however, the mean concentration observed in this station was no significantly higher than what was observed in other two stations. The higher concentration of $\mathrm{Pb}$ at Mbiri (site one), which is located in the upstream reaches of the Orogodo River may have been due to the numerous anthropogenic activities occurring at this water front (washing of cars and motor bikes). Washbay effluent is toxic and impacts downstream sites [20], though it has 
scarcely received attention in pollution studies in Nigeria. We observed relatively higher concentrations of $\mathrm{Cd}, \mathrm{Zn}$ and $\mathrm{Fe}$ in water sampled at site 3 , Obazagbon. This site is the lowest downstream point in this study, thus, it tends to collect sewage effluent released from upstream activities. Moreso, there is an immediate open sewage channel which discharge close to the site hence this could explain the high concentrations of $\mathrm{Cd}$, Fe and $\mathrm{Zn}$ recorded. Open dumping of market waste is rife at this site such that metal laden leachate could be enriching the concentrations of $\mathrm{Cd}, \mathrm{Zn}$ and $\mathrm{Pb}$. There was a significant temporal variation in the concentrations of $\mathrm{Cd}, \mathrm{Cu}, \mathrm{Fe}, \mathrm{Pb}$ and $\mathrm{Zn}$, with markedly higher concentrations observed in the dry months of November, December, January, February and March. This may have been due to reduced water volume owing to higher temperatures and increased evaporation during the dry season [21]. There were significant spatial differences in metal concentrations in water regardless of the season. This is attributable to different spatial anthropogenic activities, and geogenic backgrounds of the three sites. Such that any metal pollution redress and habitat rehabilitation program should consider site specific hydrodynamics, morphometrics and hydraulics [22].

In this study, it was observed that the concentration of $\mathrm{Zn}, \mathrm{Cu}$ and $\mathrm{Fe}$ in water were lower than the maximum recommended limit while the level of $\mathrm{Pb}$ and $\mathrm{Cd}$ was higher than the values recommended by [23] and [24]. The elements $\mathrm{Pb}$ and $\mathrm{Cd}$ are more toxic and persistent, and thus our finding points to the need for urgent redress to minimize their effects and risks on human health in the Orogodo River. Though, the concentrations of trace elements $\mathrm{Zn}, \mathrm{Cu}$ and $\mathrm{Fe}$ are lower than the WHO thresholds, it is prudent to institute long term monitoring action as they are toxic at elevated levels [4].

\subsection{Heavy Metals in Fish}

Aquatic animals (including fish) bioaccumulate trace metals in considerable amounts metals and store it over a long period of time in the bone, liver and gills as a result of their different physiological roles [14]. The high accumulation of heavy metals in these components can result in serious ecological changes. One of the most serious results of the persistence of these metals is their biological amplification in the food chain. In this study, the mean levels of $\mathrm{Cd}, \mathrm{Fe}, \mathrm{Pb}$ and $\mathrm{Zn}$ in fish ranked higher during the dry season months (November, December, January, February and March) as compared to the rainy season month (April). Similar trend was also observed by [25] in Erpetoichthys calabaricus obtained from Ogba River, Edo State. They attributed the trend to increased evaporation during the dry season. The rate of bioaccumulation of heavy metals in aquatic organisms depends on the ability of the organisms to metabolize the metals and the concentration of such metal in the river. The bioaccumulation of heavy metals varied between species, ages, sex and organs. In general, the target tissues of heavy metals are metabolic active ones which accumulate high levels of metal in fish such as liver and gills, whereas in muscles where the metabolic activity is relatively low accumulates less level of heavy metals [13]. In this study, higher level of $\mathrm{Pb}$ and $\mathrm{Cu}$ were recorded in $P$. ansorgei as compared to other fish species while $P$. obscura had higher concentration of $\mathrm{Cd}, \mathrm{Zn}$ and Fe as compared to other fish species. It was observed that the concentration of $\mathrm{Pb}, \mathrm{Cd}, \mathrm{Zn}$ and $\mathrm{Fe}$ in fish obtained during the study were higher than the values recommended by [26] and [24] while the concentration of $\mathrm{Cu}$ was lower than the recommended values by the aforementioned bodies (FAO and $\mathrm{WHO}$ ).

\subsection{Bioaccumulation Quotient (BQ)}

The Bioaccumulation Quotient of the metals in all the species investigated was greater than 1 thus indicating that there was bioaccumulation of all the metals in this study, however, the highest $B Q$ value was observed for $\mathrm{Fe}$ in $P$. ansorgei. The high $\mathrm{BQ}$ observed in Fe may have been due to the high concentration observed in water. [27] asserted that heavy metal concentration in aquatic fauna is often proportional to the levels in the aquatic environment in which the fauna resides. The variations in the $B Q$ value observed in the fish species may have resulted from variations in feeding habits or age of the fish species. [28] observed a lower concentration of heavy metals in pelagic fishes than those of benthic fishes. However, the $\mathrm{BQ}$ for $\mathrm{Cu}, \mathrm{Zn}$ and $\mathrm{Pb}$ recorded in this study were higher than values observed by [29] for $\mathrm{Cu}$ (1.06), Zn (50.13) and $\mathrm{Pb}(1.55)$ in Crossostrea gasar. 


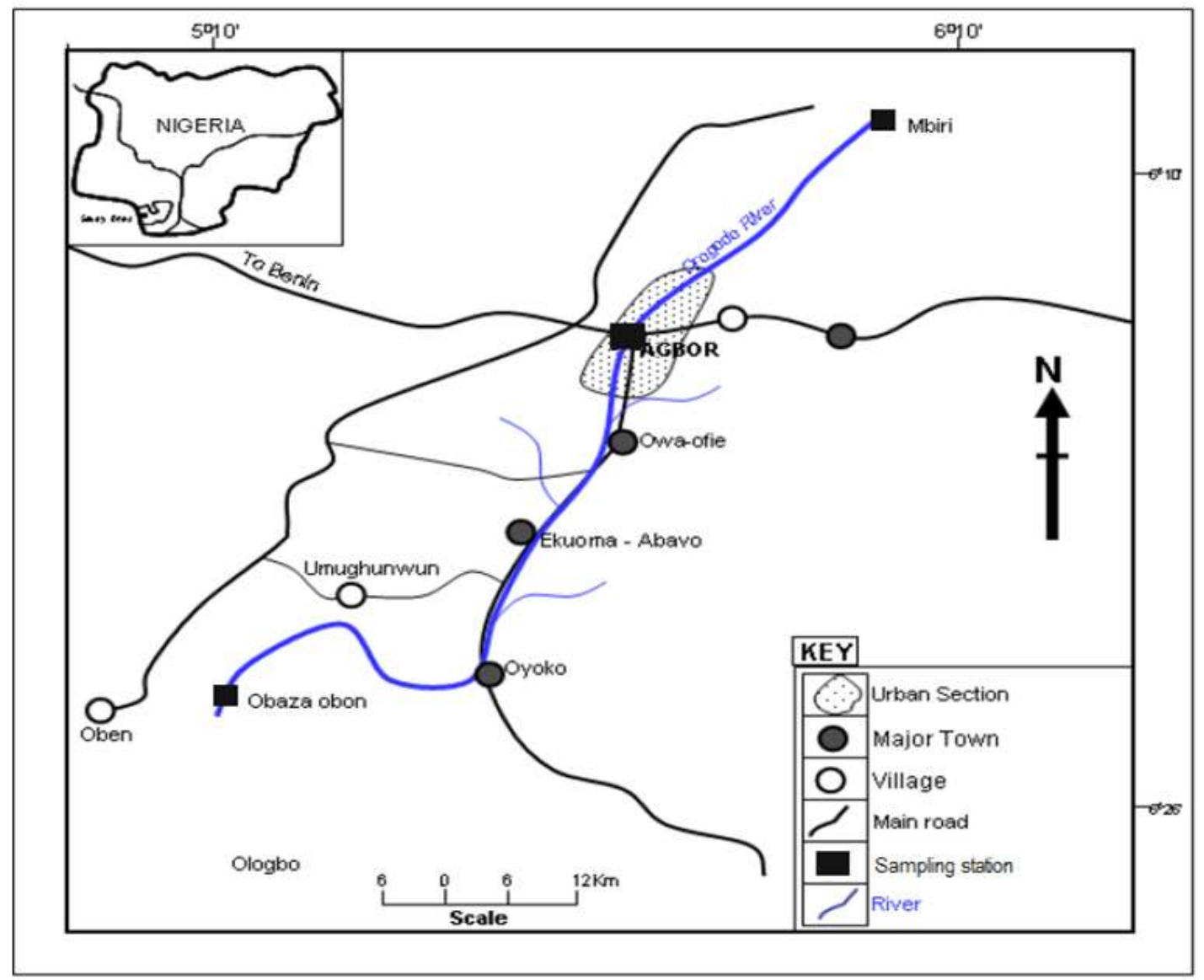

Fig. 1. Map of study area showing sampling stations Source: [30]

Table 1. Mean $( \pm \mathrm{SD})$ concentration of heavy metals $(\mathrm{mg} / \mathrm{l})$ in water obtained from the sampling stations

\begin{tabular}{llllll}
\hline Stations & $\mathbf{P b}$ & $\mathbf{C d}$ & $\mathbf{C u}$ & $\mathbf{Z n}$ & $\mathbf{F e}$ \\
\hline Mbiri & $0.020^{\mathrm{a}} \pm 0.008$ & $0.003^{\mathrm{a}} \pm 0.001$ & $0.025^{\mathrm{a}} \pm 0.018$ & $0.079^{\mathrm{a}} \pm 0.052$ & $0.133^{\mathrm{a}} \pm 0.062$ \\
Agbor & $0.012^{\mathrm{a}} \pm 0.009$ & $0.005^{\mathrm{a}} \pm 0.002$ & $0.035^{\mathrm{a}} \pm 0.021$ & $0.077^{\mathrm{a}} \pm 0.054$ & $0.122^{\mathrm{a}} \pm 0.014$ \\
Obazagbon & $0.008^{\mathrm{a}} \pm 0.004$ & $0.008^{\mathrm{a}} \pm 0.003$ & $0.030^{\mathrm{a}} \pm 0.025$ & $0.095^{\mathrm{a}} \pm 0.045$ & $0.195^{\mathrm{a}} \pm 0.101$ \\
\hline
\end{tabular}

Table 2. Mean $( \pm \mathrm{SD})$ concentration of heavy metals $(\mathrm{mg} / \mathrm{l})$ in water during the study period

\begin{tabular}{llllll}
\hline Months & $\mathbf{P b}$ & $\mathbf{C d}$ & $\mathbf{C u}$ & $\mathbf{Z n}$ & $\mathbf{F e}$ \\
\hline November & $0^{\mathrm{a}} \pm 0$ & $0^{\mathrm{a}} \pm 0$ & $0.04^{\mathrm{bcd}} \pm 0.02$ & $0.08^{\mathrm{a}} \pm 0.05$ & $0.04^{\mathrm{a}} \pm 0.02$ \\
December & $0.02^{\mathrm{a}} \pm 0.01$ & $0^{\mathrm{a}} \pm 0$ & $0.03^{\mathrm{bc}} \pm 0.02$ & $0.17^{\mathrm{b}} \pm 0.12$ & $0.35^{\mathrm{b}} \pm 0.29$ \\
January & $0.03^{\mathrm{a}} \pm 0.02$ & $0.07^{\mathrm{ab}} \pm 0.02$ & $0.01^{\mathrm{a}} \pm 0.01$ & $0.04^{\mathrm{a}} \pm 0.03$ & $0.16^{\mathrm{a}} \pm 0.09$ \\
February & $0.01^{\mathrm{a}} \pm 0.01$ & $0^{\mathrm{a}} \pm 0$ & $0.02^{\mathrm{ab}} \pm 0.02$ & $0.07^{\mathrm{a}} \pm 0.04$ & $0.10^{\mathrm{a}} \pm 0.06$ \\
March & $0.01^{\mathrm{a}} \pm 0.01$ & $0.01^{\mathrm{b}} \pm 0.01$ & $0.04^{\mathrm{d}} \pm 0.02$ & $0.06^{\mathrm{a}} \pm 0.04$ & $0.11^{\mathrm{a}} \pm 0.08$ \\
April & $0.01^{\mathrm{a}} \pm 0.01$ & $0.01^{\mathrm{b}} \pm 0.01$ & $0.04^{\mathrm{cd}} \pm 0.01$ & $0.08^{\mathrm{a}} \pm 0.03$ & $0.14^{\mathrm{a}} \pm 0.08$ \\
WHO threshold & 0.01 & 0.01 & 2.00 & 3.0 & 0.3 \\
SON threshold & 0.01 & 0.01 & 1 & 3 & 0.3 \\
\hline
\end{tabular}


Table 3. Mean ( \pm SD) concentration of heavy metals $(\mathrm{mg} / \mathrm{kg})$ in fish during the study period

\begin{tabular}{llllll}
\hline Months & $\mathbf{P b}$ & $\mathbf{C d}$ & $\mathbf{C u}$ & $\mathbf{Z n}$ & $\mathbf{F e}$ \\
\hline November & $0.60^{\mathrm{a}} \pm 0.47$ & $0.18^{\mathrm{a}} \pm 0.10$ & $1.97^{\mathrm{a}} \pm 1.33$ & $48.97^{\mathrm{ab}} \pm 22.12$ & $3.5^{\mathrm{a}} \pm 1.2$ \\
December & $2.31^{\mathrm{a}} \pm 1.98$ & $0.03^{\mathrm{a}} \pm 0.01$ & $3.73^{\mathrm{ab}} \pm 2.98$ & $70.34^{\mathrm{b}} \pm 35.21$ & $286.1^{\mathrm{a}} \pm 123.2$ \\
January & $2.40^{\mathrm{ab}} \pm 2.13$ & $0.47^{\mathrm{a}} \pm 0.38$ & $6.56^{\mathrm{abc}} \pm 4.32$ & $82.30^{\mathrm{b}} \pm 54.32$ & $100.3^{\mathrm{abc}} \pm 89.1$ \\
February & $0.71^{\mathrm{a}} \pm 0.58$ & $0.12^{\mathrm{a}} \pm 0.15$ & $6.86^{\mathrm{bc}} \pm 3.25$ & $22.96^{\mathrm{a}} \pm 15.41$ & $22.0^{\mathrm{ab}} \pm 12.8$ \\
March & $2.68^{\mathrm{b}} \pm 1.97$ & $0.26^{\mathrm{a}} \pm 0.22$ & $10.56^{\mathrm{c}} \pm 4.67$ & $73.06^{\mathrm{b}} \pm 34.67$ & $179.6^{\mathrm{bcd}} \pm 119.3$ \\
April & $2.21^{\mathrm{ab}} \pm 2.01$ & $0.25^{\mathrm{a}} \pm 0.19$ & $10.57^{\mathrm{c}} \pm 3.27$ & $72.06^{\mathrm{b}} \pm 43.21$ & $186.8^{\mathrm{cd}} \pm 101.8$ \\
FAO threshold & 0.5 & 0.5 & 30 & 30 & 100 \\
\hline
\end{tabular}

Table 4. Heavy metals (Mean \pm SD) in fish species obtained for the period November-April

\begin{tabular}{llllll}
\hline Fish species & $\mathbf{P b}$ & $\mathbf{C d}$ & $\mathbf{C u}$ & $\mathbf{Z n}$ & $\mathbf{F e}$ \\
\hline Clarias gariepinus & $1.87^{\mathrm{ab}} \pm 0.54$ & $0.195^{\mathrm{a}} \pm 0.071$ & $7.97^{\mathrm{de}} \pm 3.42$ & $52.61^{\mathrm{b}} \pm 32.13$ & $125.03^{\mathrm{ab}} \pm 78.92$ \\
Brycinus intermidus & $0.57^{\mathrm{a}} \pm 0.23$ & $0.060^{\mathrm{a}} \pm 0.010$ & $4.00^{\mathrm{b}} \pm 1.85$ & $77.08^{\mathrm{c}} \pm 34.10$ & $60.20^{\mathrm{a}} \pm 26.51$ \\
Parachanna obscura & $2.60^{\mathrm{b}} \pm 1.23$ & $0.615^{\mathrm{b}} \pm 0.235$ & $6.97^{\mathrm{cd}} \pm 2.34$ & $91.62^{\mathrm{c}} \pm 54.21$ & $187.90^{\mathrm{bc}} \pm 89.59$ \\
Phractolemus ansorgei & $2.76^{\mathrm{b}} \pm 1.76$ & $0.100^{\mathrm{a}} \pm 0.081$ & $10.07^{\mathrm{a}} \pm 6.78$ & $71.09^{\mathrm{bc}} \pm 44.32$ & $274.15^{\mathrm{c}} \pm 67.87$ \\
Ctenopoma kingsleyae & $0.29^{\mathrm{a}} \pm 0.11$ & $0.230^{\mathrm{a}} \pm 0.120$ & $1.34^{\mathrm{a}} \pm 0.89$ & $28.30^{\mathrm{a}} \pm 12.35$ & $5.70^{\mathrm{a}} \pm 2.31$ \\
Hemichromis bimaculatus & $0.06^{\mathrm{a}} \pm 0.02$ & $0.150^{\mathrm{a}} \pm 0.090$ & $5.11^{\mathrm{bc}} \pm 3.21$ & $14.08^{\mathrm{a}} \pm 6.87$ & $11.0^{\mathrm{a}} \pm 4.53$ \\
FAO threshold & 0.5 & 0.5 & 30 & 30 & 100 \\
\hline
\end{tabular}

Table 5. Bioaccumulation quotient (BQ) in fish species obtained for the period November-April

\begin{tabular}{lllllll}
\hline $\begin{array}{llll}\text { Fish } \\
\text { species }\end{array}$ & C. gariepinus $\boldsymbol{B}$. intermidus & $\boldsymbol{P}$. obscura & $\boldsymbol{P}$. ansorgei & C. kingsleyea & H. bimaculatus \\
\hline $\mathrm{Pb}$ & 140.60 & 42.57 & 195.49 & 207.52 & 21.80 & 4.51 \\
$\mathrm{Cd}$ & 34.82 & 10.71 & 109.82 & 17.86 & 47.06 & 26.79 \\
$\mathrm{Cu}$ & 265.67 & 133.33 & 232.33 & 334.67 & 44.67 & 170.33 \\
$\mathrm{Zn}$ & 630.82 & 924.22 & 1098.56 & 852.40 & 339.33 & 168.82 \\
$\mathrm{Fe}$ & 833.33 & 401.33 & 1252.67 & 1297.13 & 38.00 & 73.33 \\
\hline
\end{tabular}

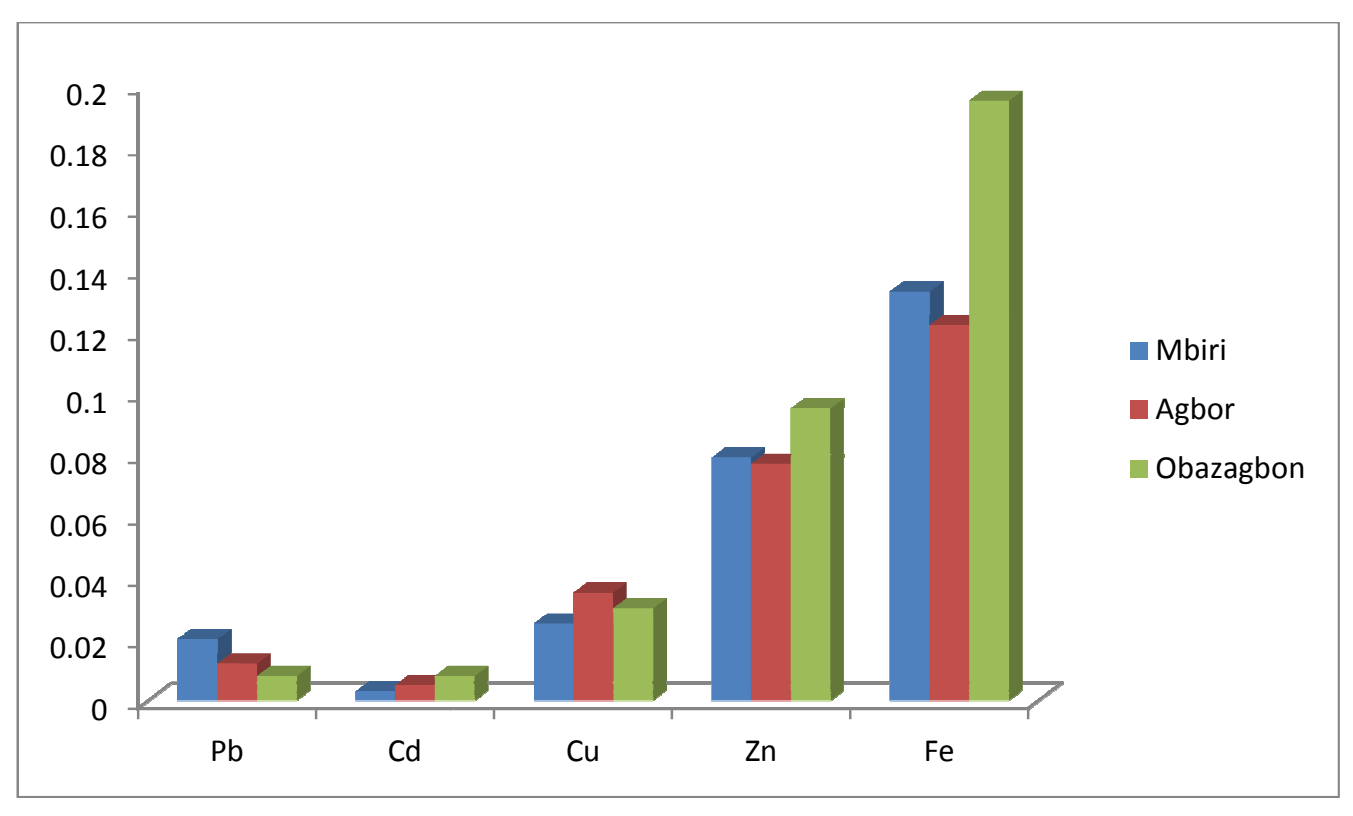

Fig. 2. Heavy metal in water obtained from the sampling stations 


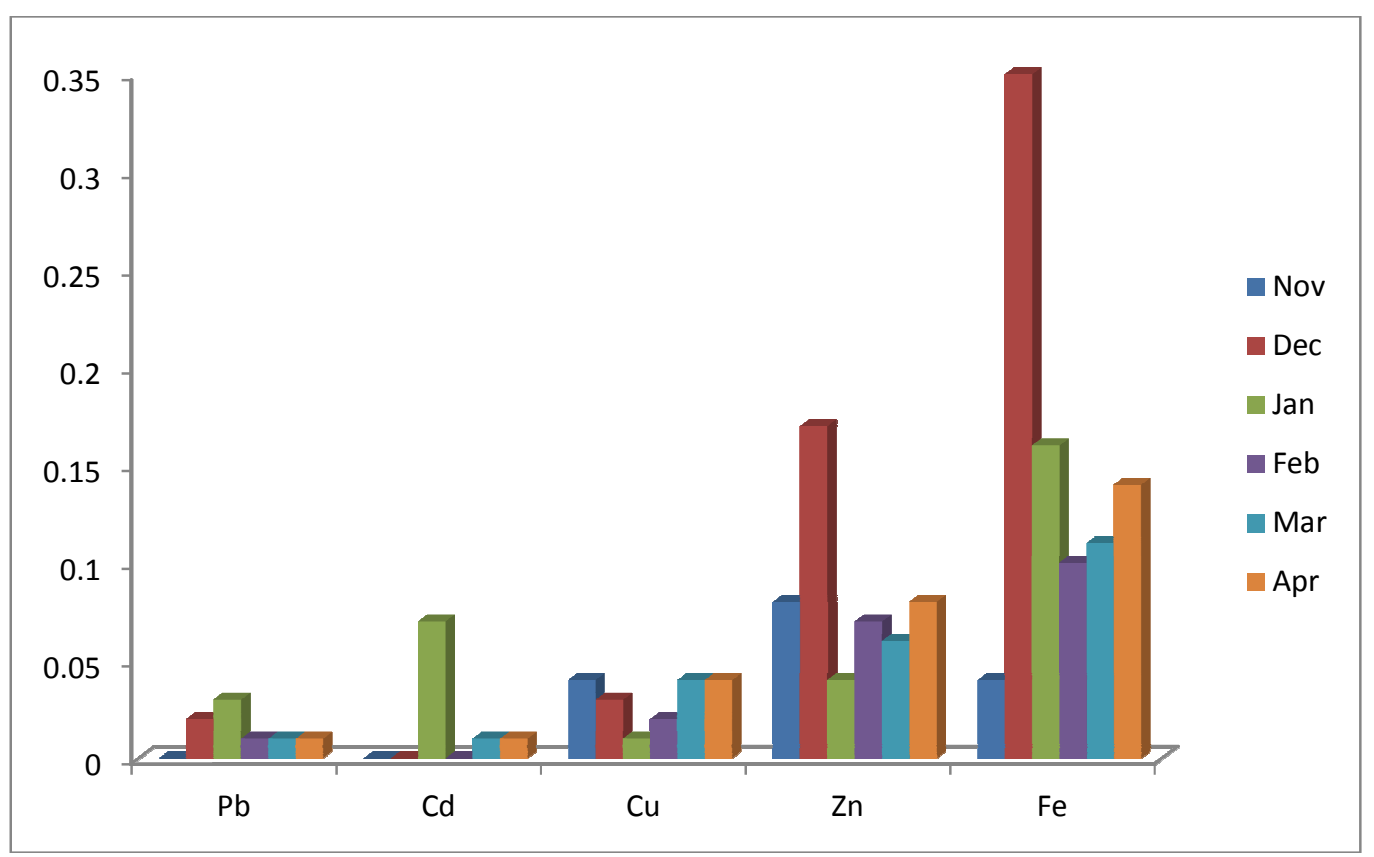

Fig. 3. Heavy metals in water during the study

\section{CONCLUSION}

The study show that the concentration of $\mathrm{Zn}, \mathrm{Cu}$ and $\mathrm{Fe}$ in water were lower than the maximum recommended limit while the concentration of $\mathrm{Pb}$ and $\mathrm{Cd}$ was higher than the values recommended by [23] and [24]. Also, the concentration of $\mathrm{Pb}, \mathrm{Cd}, \mathrm{Zn}$ and $\mathrm{Fe}$ were higher than the values recommended by [26] and [24] while the concentration of $\mathrm{Cu}$ was lower than the recommended values by the aforementioned bodies. The concentration of these heavy metals in the fish and water thus indicate that it will have cumulative deleterious effect on any aquatic organism and man who feeds on the fish and use the water. Thus it is recommended for proper waste water treatment and possibly it may be channeled from drainages into farmlands for irrigation purposes. At a local scale there is need for carrying out massive awareness campaign on the environmental hazards of improper refuse disposal through the various forms of media. This will help in enlightening the public on their individual roles as regarding wastewater generation and constituents.

\section{COMPETING INTERESTS}

Authors have declared that no competing interests exist.

\section{REFERENCES}

1. Orjiekwe CL, Dumo DT, Chinedu NB. Assessment of water quality of Ogbese River in Ovia North-East Local Government Area of Edo State, Nigeria. Int. J. Biol. Chem. Sci. 2013;7(6):25812590.

2. Paul B. Tchounwou, Clement G. Yedjou, Anita K. Patlolla, Dwayne J. Sutton Heavy metals toxicity and the environment. Molecular, Clinical and Environmental Toxicology. 2014;101:133-164.

3. Du Preez M, Govender D, Bouwman $\mathrm{H}$. Heavy metals in muscle tissue of healthy crocodiles from the Kruger National Park, South Africa. African Journal of Ecology. 2016;54(4):519-523.

4. Sparks B, Mullins B. Metal concentrations in the helderberg marine protected area, False Bay, Cape Town. Research Journal of Environmental Toxicology. 2017;11:1119.

5. Alloway BJ. Heavy metals in soils. John Wiley and Sons, Inc. New York; 1990. ISBN: 0470215984

6. Utete B, Nhiwatiwa T, Barson M, Mabika $N$. Metal correlations and mobility in sediment and water from the Gwebi River in the Upper Manyame Catchment, Zimbabwe. Int. J. Water Sci. 2013;2(4):1-8. 
7. Khair $\mathrm{MH}$. Toxicity and accumulation of copper in Nannochloropsis oculata (Eustigmatophycea, Heterokonta). World Applied Sciences Journal. 2009;6(3):378384.

8. Nkonyeasua Kingsley Egun. Effect of channelling wastewater into water bodies: A case study of the Orogodo River in Agbor, Delta State. J Hum Ecol. 2010; $31(1): 47-52$.

9. Oyem IM, Oyem $\mathrm{HH}$, Oyem MN, Usese Al, Ezeweali D, Obiwulu EN. An investigation into ground water contamination in Agbor and Owa communities in Nigeria. Sacha Journal of Environmental Studies. 2015; 5(1):28-35.

10. Wepener V, Van Dyk C, Bervoets L, O'brien G, Covaci A, Cloete Y. An assessment of the influence of multiple stressors on the Vaal River, South Africa. Phys. Chem. Earth. 2011;36:949-962.

11. Luoma SN, Rainbow PS. Metal contamination in aquatic environments: science and lateral management. Cambridge University Press, Cambridge; 2008.

12. Krishna PV, Jyothirmayi V, Madhusudhana Rao K. Human health risk assessment of heavy metal accumulation through fish consumption, from Machilipatnam Coast, Andhra Pradesh, India. International Research Journal of Public and Environmental Health. 2014;1(5):121-125.

13. Alaa M. Younis, Hesham F. Amin, Ali Alkaladi, Yahia Y. I. Mosleh. Bioaccumulation of heavy metals in fish, squids and crustaceans from the Red Sea, Jeddah Coast, Saudi Arabia. Open Journal of Marine Science. 2015;5:369-378.

14. Fredrick Asante, Etornyo Agbeko, Georgina Addae, Albert K. Quainoo. Bioaccumulation of heavy metals in water, sediments and tissues of some selected fishes from the Red Volta, Nangodi in the Upper East Region of Ghana. British Journal of Applied Science \& Technology. 2014;4(4):594-603.

15. Avwunudiogba A. A comparative analysis of soil and nutrient losses on maize plant with different tillage practices in Ikpoba River Basin of South-Western Nigeria. Nigerian Geographic Journal, New Series. 2000;3(4):199-208.

16. Puyate YT, Rim-Rukeh A, Awatefe JK. Metal pollution assessment and particle size distribution of bottom sediment of Orogodo River, Agbor, Delta State,
Nigeria. Journal of Applied Sciences Research. 2007;3(12):2056-2061.

17. Meye JA, Ikomi RB. Seasonal fish abundance and fishing gear efficiency in River Orogodo, Niger Delta, Nigeria. World Journal of Fish and Marine Sciences. 2012;4(2):191-200.

18. Greenberg AE, Connors JJ, Jenkins D. Standard methods for the examination of water and wastewater $\left(15^{\text {th }}\right.$ edn). Washington, DC: American Public Health Association; 1980.

19. Adedeji OB, Okocha RC. Assessment level of heavy metals in prawns (Macrobrachium macrobrachium) and water from Epe Lagoon. Advances in Environmental Biology. 2011;5(6):1342-1345.

20. Danha C, Utete B, Soropa G, Rufasha SB. Potential impact of wash bay effluent on the water quality of a subtropical river. Journal of Water Resource and Protection. 2014;6:1045-1050.

21. Wetzel RG. Limnology: Lake and river ecosystems. San Diego: Academic Press. 2001;1006.

22. Utete Beaven, Joshua Tsamba, Exeverino Chinoitezvi, Blessing Kavhu. Analysis of the abundance and spatial distribution of the common hippopotamus, (Hippopotamus amphibius) in the Manjirenji Dam, Zimbabwe, to inform conservation and detect human-wildlife conflict hotspots. African Journal of Ecology. 2017;1-6.

23. Standard Organization of Nigeria. Nigerian standard for drinking water quality. Nigerian Industrial Standard. 2007;30.

24. World Health Organization. Guidelines for drinking-water quality. $3^{\text {rd }}$ Edition, Recommendations of WHO, Geneva. 2006;1:515.

25. Obasohan EE, Eguavoen OI. Seasonal variations of bioaccumulation of heavy metals in a freshwater fish (Erpetoichthys calabaricus) from Ogba River, Benin City, Nigeria. Afr. J. Gen. Agric. 2008;4(3):153163.

26. Food and Agriculture Organization, FAO. Compilation of legal limits for hazardous substances in fish and fishery products. FAO Fisheries Circular No. 464. 2008;5100.

27. Akueshi EU, Oriegie E, Ocheakiti N, Okunsebor. Levels of some heavy metals in fish from mining lakes on the Jos pleateau, Nigeria. Afr. J. Nat. Sci. 2003;6: 82-86. 
28. Romeo M, Siau Y, Sidoumou Z, GnassiaBarell M. Heavy metal distribution in different fish species from Mauritania coast. Sci. Total Environ. 1999;232:169175.

29. Wangboje OM, Oronsaye JAO, Okeke EC. The use of the mangrove oyster (Crossostrea gasar) as a bio-indicator for chemical element contamination in the
Niger Delta. African Journal of Food, Agriculture, Nutrition and Development. 2014;14(3):8903-8919.

30. Mogborukor JOA. Morphological adjustment of a tropical river to urbanization. International Journal of Applied Science and Technology. 2014; 4(4):169-179.

(c) 2017 Wangboje et al.; This is an Open Access article distributed under the terms of the Creative Commons Attribution License (http://creativecommons.org/licenses/by/4.0), which permits unrestricted use, distribution, and reproduction in any medium, provided the original work is properly cited.

Peer-review history:

The peer review history for this paper can be accessed here: http://sciencedomain.org/review-history/19620 